\title{
Sufis' Centers as Scientific and Educational Institutions by Reference to the Manuscripts Transcribed There
}

\author{
Habibollah Azimi \\ National library of Iran, Tehran, Iran \\ Email: habibazimi@yahoo.com
}

How to cite this paper: Azimi, H. (2018). Sufis' Centers as Scientific and Educational Institutions by Reference to the Manuscripts Transcribed There. Advances in Historical Studies, 7, 163-178.

https://doi.org/10.4236/ahs.2018.74011

Received: July 1, 2018

Accepted: December 27, 2018

Published: December 30, 2018

Copyright $\odot 2018$ by author(s) and Scientific Research Publishing Inc. This work is licensed under the Creative Commons Attribution International License (CC BY 4.0).

http://creativecommons.org/licenses/by/4.0/

\begin{abstract}
Sufism is an ascetic way among Muslims based on comportment for purifying the self and avoiding the world for reaching God and completing the soul. Sufis established several independent religious-military centers under different names, such as Khāngāh, Zawiya, Mazār, Takya, Rebaț, Madrasa, Şawmi’a and so on in order to teach, meet, worship and discuss, publicize and live in. They had libraries where Sufism-related or other books were collected.
\end{abstract}

\section{Keywords}

Manuscript Transcription, Sufi's Centers, Iran's Libraries

\section{Introduction}

Research Aim: As there is historical evidence that practical Sufism was taught in khānqāhs and other Sufis' centers, they had some role in teaching religious fields such as Fiqh, hadith, Koranic sciences, medicine and literature in parallel with mosques and madrasas. This study aimed to describe the role of Sufism centers in teaching Islamic sciences in different historical periods by reference to manuscripts transcribed and/or compiled in these centers.

Research Population \& Method: This included 300,000 manuscripts. Their bibliographic information was published in the 40-volume Union Catalogue of Iran Manuscript. The transcription centers of the manuscripts were investigated by using some keywords related to Sufis' centers, such as Khāngāh, Rebaț,Mazar and Zawiya.

Research Findings: 1 ) From the $4^{\text {th }}$ and $5^{\text {th }}$ to $13^{\text {th }}$ centuries A. H., Sufis' centers, such as khānqāh, zawiya, mazār, takya, ribāț, madrasa, and sawmi’a, had 
different educational roles, such as transcription as well as being centers for worship and Sufism tradition. 2) Most transcription efforts in Sufis' centers have been done in the $8^{\text {th }}$ and $9^{\text {th }}$ centuries A. H. Sufis' scientific centers were mostly khānqāhs, zawiyas, madrasas, and buq'as. 3) Considering the vast development of Sufism in Khurāsān and Fārs in the $4^{\text {th }}$ and $5^{\text {th }}$ centuries A. H., most studied Sufism centers were belonged to Iran. Egypt was another country where these centers were more due to the Mamluk dynasty (648-923 A. H.) and their tendency to build and reconstruct educational centers, such as madrasas, masques and khānqāhs. 4) Scribes in Sufis' centers tended to transcribe manuscripts on Sufism. However, those in other centers, such as Madrasas and mosques, tended to transcribe manuscripts on grammar, fiqh, hadith and Koranic interpretation.

\section{Transcribing in Sufi's Centers}

Investigating into over 300,000 manuscripts cataloged in Iran's libraries and introduced in 40 volumes of Iranian manuscript union catalog (published in $\mathrm{Na}$ tional library of Iran 2012-2016 by Derayatimostafa), 60 manuscripts were found to be transcribed in Khanqahs and similar centers.

Research population: This included 300,000 manuscripts. Their bibliographic information was published in Union Catalogue of Iran Manuscript and their transcription places were indicated by their scribes in a passage at the end of each manuscript.

Research Method: The transcription centers of the manuscripts were investigated by using some keywords related to Sufis' centers, such as Khāngāh, Mazar and Zawiya. After extracting related data from the union catalog, data items were classified and presented in tables as to the research questions.

Literature Review: Almost all reviewed studied concentrated on history of the performance of Sufis' centers in different places and periods. There was no research that concentrated on writing and transcribing scientific works in these centers. Some main studies are briefly described here:

1) Understanding the Concept of Islamic Sufism/Shahida Bilqies/Shah-i-Hamadan Institute of Islamic Studies/University of Kashmir, Srinagar-190006/Jammu and Kashmir, India/Journal of Education \& Social Policy Vol. 1 No. 1; June 2014.

Some of the topics discussed: Etymology of the Word Sufi/Definitions of Sufism/Various Sayings on Sufism/Words of the Masters Concerning the Term Sufi/Tassawufin the light of Qur'an and Hadith/Sources of Sufism/Nature and Purpose of Sufism/Sufi Philosophy/Theories/The Foundation of Sufism/Principal Teachings of Sufism/The Four Stages of Sufism/Categories of Sufis/Three Dimensions of Sufism/Characteristics of a Sufi.

2) A Short Introduction to Origin, Beginning and History of Sufism or Tasawwuf/1AJAY KUMAR GHOSH, 2SUMEER AHMAD MIR (Barkatullah University Bhopal)-Madhya Pradesh, India.

International Journal of Management and Applied Science, ISSN: 2394-7926 Volume-2, Issue-12, Dec.-2016. 
Some of the topics discussed: Origin, Beginning and History of Sufism or Tasawwuf.

3) Sufism and Sufi Orders: God's Spiritual Paths/Adaptation and Renewal in the Context of Modernization/Hassan Abu Hanieh/December 2011/Published in 2011 by Friedrich-Ebert-Stiftung.

Amman Of_ce/P.O. Box 926238, Amman/Jordan.

Some of the topics discussed:Islamic Sufism's Historical Formation/The Sufi Approach: Wisal and Wusul/Sufi Orders in Jordan.

4) The Origin and Evolution of Sufism/Dr. Farida Khanam/Al-Idah 2011 The Origin and Evolution of Sufism 21.

Some of the topics discussed:The Beginnings of Sufism/Sufi links with Orthodoxy/The Sufi way $(\wedge$ arìqah)/.

5) Educational Characteristics of Sufi Brotherhoods/Muhammad Faisal \&Pauzi.

Proceedings of the 1st International Conference on Character Education Batam, 23 August 2015.

Some of the topics discussed: Educational Institution of Sufi/Forms and Functions of Sufis Educational Institutions/Educational Characteristics of Sufis Brotherhoods.

6) The Origin of Mysticism and Sufism in Hadith/Seyyed Muhammad Rastgoo Far \& Mahdi Dasht Bozorgi/Religious Inquiries Vol. 2, No. 3, Winter and Spring 2013, 103-117.

Some of the topics discussed: The Connection between Mysticism and Piety/Some Examples of Mystic Principles and Their Relation to Hadiths.

7) Sufism an Introduction/Farida khanam

First published in 2006/Reprinted 2007/First revised edition 2009/Printed in India.

Some of the topics discussed: The Origin and Evolution of Sufism/Towards Mysticism/The Sufi Concept of Meditation/Tasawwuf Today.

8) Introduction to Sufi Doctrine/Titus Burckhardt

Foreword by: William C. Chittick Printed on acid-free paper in Canada./For information address World Wisdom, Inc./P.O. Box 2682, Bloomington, Indiana 47402-2682.

Some of the topics discussed: Part 1: The Nature of Sufism/Part 2: The Doctrinal Foundations /Part 3: Spiritual Realization.

\section{Sufism in Islam}

Sufism is an ascetic way among Muslims based on comportment for purifying the self and avoiding the world for reaching God and completing the soul. Sufism in Arabic (taşawwuff) means wearing woolen clothes as Sufis were wearing woolen clothes as a sign of asceticism and inner behavior. Despite its various definitions, Sufism is based on a main principle: knowing the creator of the world and discovering the reality of the creation and the human-reality connection 
through asceticism and theosophy rather than rationale and reasoning. It is appeared that Sufism was commonplace in $2^{\text {nd }}$ century A. H. in the Islamic world. Sufis in this century had no established social institution and certain thought school. In other words, in the centuries $2^{\text {nd }}$ and $3^{\text {rd }}$ A. H., Sufism had not any practical and theoretical schools in these centuries and their meeting places (Sufis' centers) was not still formed as khāngāhs.

\section{Scientists and Scholars' Transcription Centers}

In the fields of knowledge and speech and among scribes and authors, there were some customs they followed. These customs were formed in the centers other than those of court and concentrated on learning and educating circles. Scientists and scholars in the Islamic world could produce thousands of fine and valuable manuscripts in scientific fields with their own independent attempts and exercises.

Some motivations including educational, learning and religious ones were at work for writing and transcribing in the Islamic world. As a result, transcription in part was done in educational centers such as schools (for example Image 1), masques (for example Image 2 \& Image 3), Khānqāhs (so-called monasteries) and Niżämiyyas ${ }^{1}$ as well as in scientific-research centers such as observatories (Khawandmir, 1305). Students and graduates of these centers abridged, commented, explained and interpreted their selected books. Such a tradition that began from $3^{\text {th }}$ and $4^{\text {th }} \mathrm{AH}\left(9^{\text {th }}\right.$ and $\left.10^{\text {th }}\right)$ centuries continued up to later centuries (Fadā'īîrāqī, 2007: p. 13).

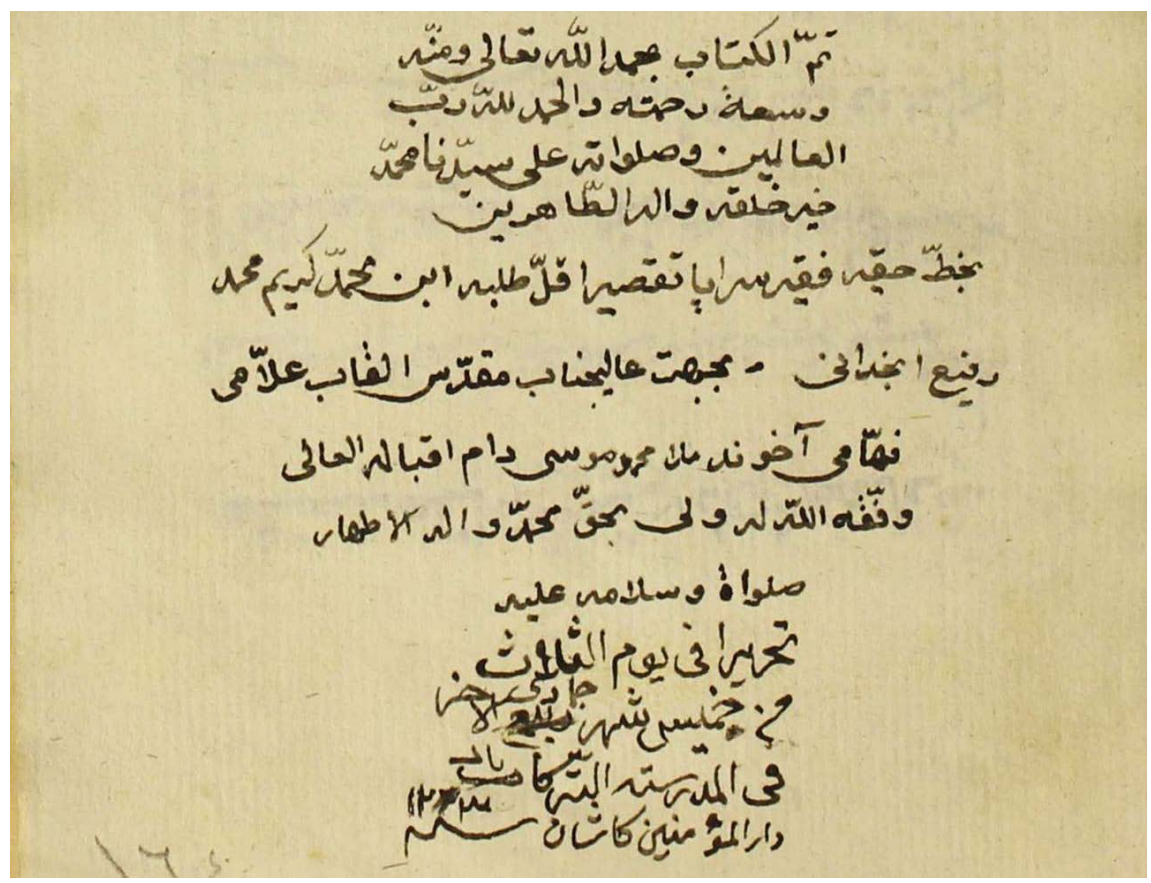

Image 1. It was transcribed in Kashān's Turkābād school.

${ }^{1}$ Nizāmiyyas were a group of the medieval institutions of higher education established by Khaja Nizām al-Mulk in Iran. 


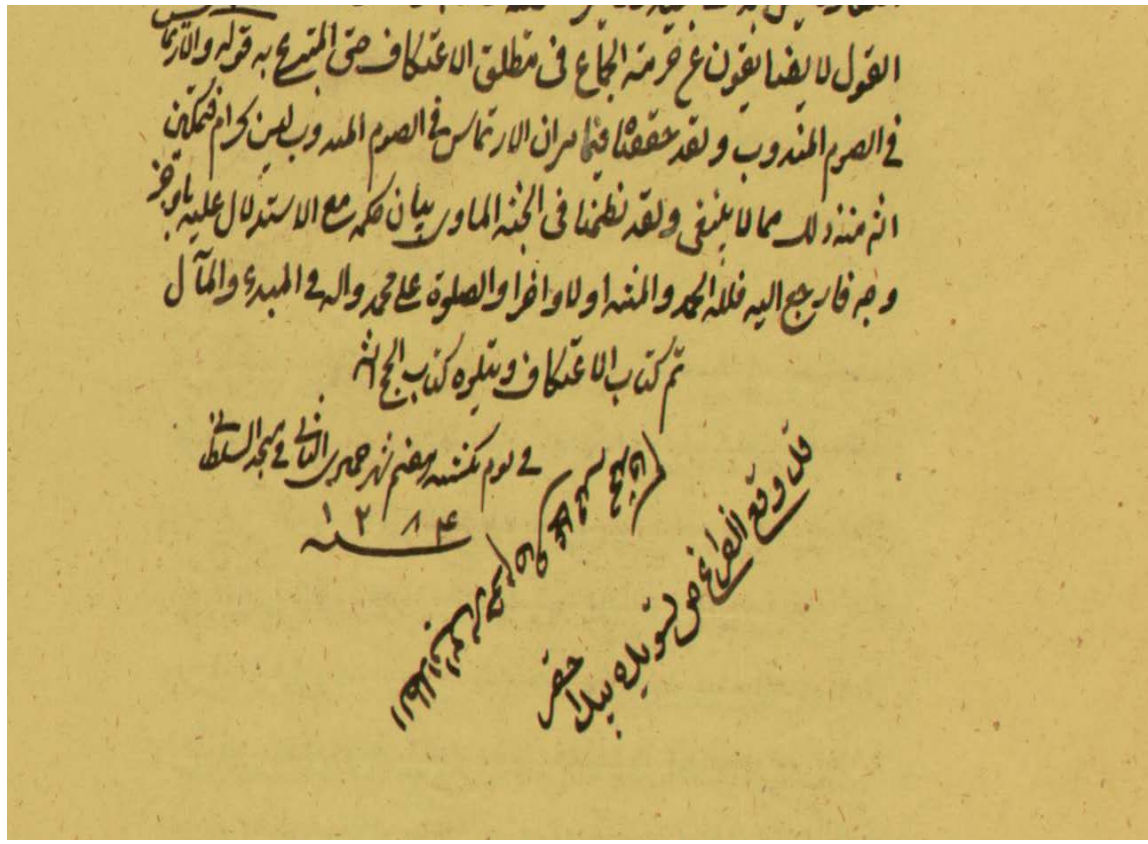

Image 2. It was transcribed in a Sulțānī mosque.

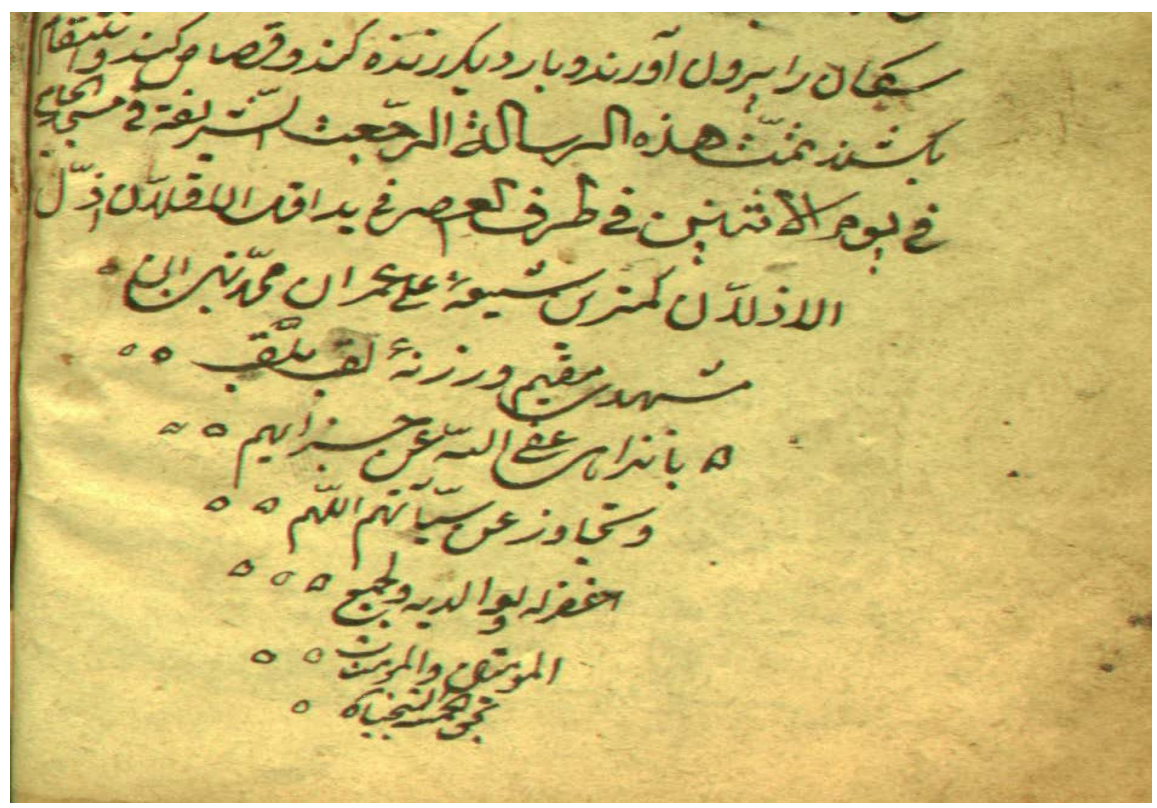

Image 3. It was transcribed in a Jāmi' (central) mosque.

\section{Sufis' Centers}

About $14^{\text {th }}$ century A. H., some certain places were established for Sufis' meetings. These places were named ribaț and zawiya in Arab countries and north-western Iran and khānqāh in other places located in Iran. There was no difference of meaning between these words. So Sufis established several independent religious-military centers under different names such as Khāngāh, Zawiya, Mazār, Takya, Robaț, Madrasa, Şawmi'a and so on in order to teach, meet, worship and discuss, publicize and live in (Kiyani, 1369: p. 17). Khāngāh was 
common name in Iran, Egypt and Syria (Mostafa Javad, p. 1007) and that of Rebaț in Arab regions and the south-western Iran for such centers.

Sufis were gradually organized in these places. In these multi-purposed places, teaching Sufi students and providing social services were organized and the setting was prepared for writing and compiling Sufism literature. Sufism elders compiled the main principles of the Sufism in these centers where education and training was focused on.

\section{Khāngāh}

As a Sufis' center, khānghāh had several uses such as instruction, gathering and life. There is no detailed information on the first khānghāhs. Many researchers related the formation of primary khānghāhs to Karrāmīān. The word khānghāh first appeared in the works by authors living in the $4^{\text {th }}$ century A. H. The anonymous author of Hudūd al-'Alam (authored around the $4^{\text {th }}$ century A. H.) described Mānavian'skhānghāh in detail.

Khāngāh was completely known in the middle of the $4^{\text {th }}$ century A. H. and it can be said that with the establishment of Sufism in the $3^{\text {rd }}$ century A. H., some especial centers were developed for Sufis' gatherings and instruction and were expanded during the $4^{\text {th }}$ and $5^{\text {th }}$ centuries A. H. (Maqdisī, p. 41). From the $5^{\text {th }}$ century A. H., the number of organized khāngāhs increased and as noted by Ibn Bațțūța in his travel literature (İbn Bațtūța, 1987), khāngāhs were increased in all Islamic countries in the $7^{\text {th }}$ and $8^{\text {th }}$ centuries and changed into main centers for Sufis, pilgrims and tourists (Dastgheib, 1376: p. 268).

In the İlkhānid dynasty, many khāngāhs were established and many Sufis were active in them. Seljuks were supporters of khānghāhs, too. With emergence of the Safavid dynasty and development of Shiat sect and under domination of fuqaha and "ulamä" (religion scientists), the sheikhs of Sufism were weakend. As a result, many Sufism groups tended to immigrate and many Khāngāhs were closed. In spite of their re-establishing in the Qājārid dynasty, khāngāhs remained under fluctuating situations due to religious-political movements in the next periods (for example Image 4).

\section{Rebāţs}

In its primary use, rebāțs was a word used for naming boundary military centers formed for protecting the Islamic area. Some centers in the boundaries of Syria, Africa and Khurāsān had such centers (Iștakhrī, p. 55). Changing in their applications, rebaţs converted into worship and instruction centers. With the same meaning as khāngāh, rebațs were common in Baghdad and Iraq. In the Abbasid dynasty, it referred back to a home for the poor and developed as a benevolent fund within and outside Baghdad (Ālūsī, 1398: pp. 113-120). Rebaț was selected to

${ }^{2}$ Hudūd al-'Alammin al-Mashriqwa al-Maghrib (The limits of the world From the east and west). By Manuchehr Sotoodeh. Tehran: Tehran University. 


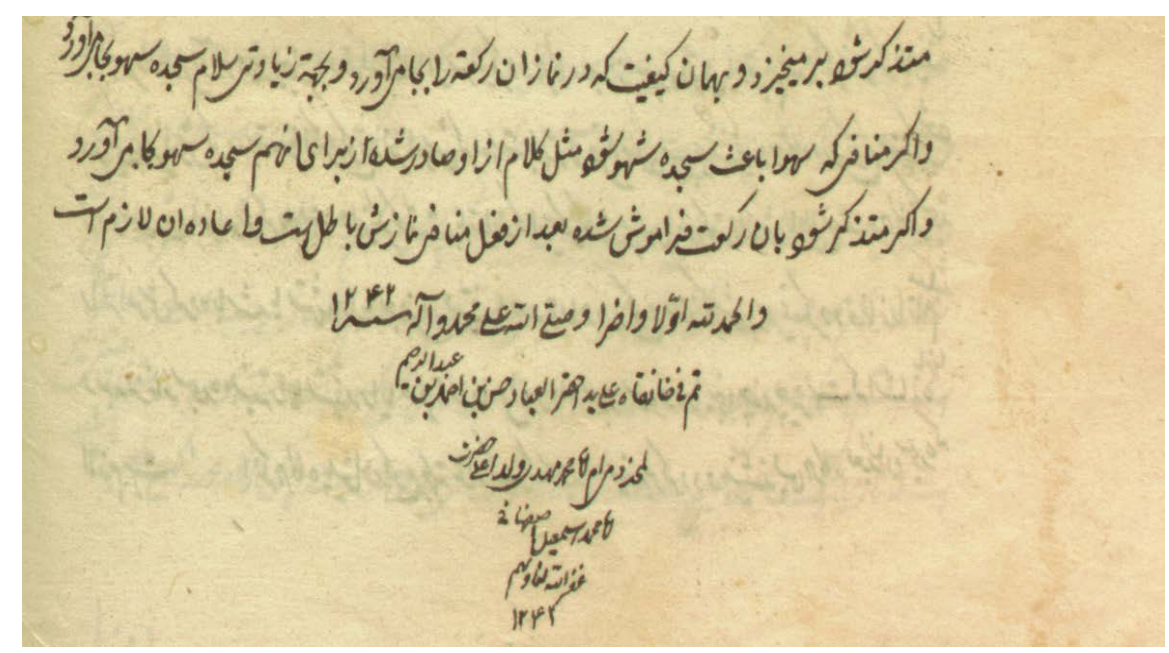

Image 4. It was transcribed in Khānqāh.

name such centers due to its political brand and was used in Egypt, too (Mușțaāā, 2006: p. 1007). Different from khāngāhs, rebațs were the centers for educating followers (Trimingham, 1971: p. 168).

\section{Zāwiyas}

Stemming from an Arabic word meaning isolation, zāwìya is a place where one isolates themselves and reads the Koran and praises Allah (Dickie, 1984; Walī, 1988). In many regions, including Africa, this word was used for naming khāngāhs. In Sufism terminology, it sometimes referred back to the room where a Sufi isolated himself. This room sometimes placed in a mosque as that in

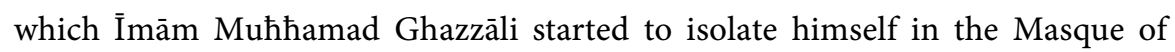
Damascus (Ibn, 1984: p. 240). Based on Ibn Baț̦ūța (1987, Vol. 1. p. 380), one of Mongol emirs established 40 zāwiyas in Ghazni.

\section{Buq'a/Maqbara}

Named variously as maqbara, ārāmgah, marqad and mazār, buq'as were the graves of Sufis, scientists and scholars and places for pilgrims. Emerging from the $5^{\text {th }}$ century A. H., buq'as were developed in the Siljuk dynasty. Shaykh Şafi al-Dīn Ardabīlì'sbuq'a was one of the famous ones functioned as his khāngāh and madrasa for teaching his followers and is his grave, too. Sometimes, Sufism sheikhs' graves functioned as a center for publicizing their teachings and sometimes, khāngāhs were built after building the maqbara, such as that of Shaykh Şafi al-Dīn Bukharī (in the $8^{\text {th }}$ century). Maqbaras and Zawlyas found important placement after the decline of khāngāhs.

\section{Takiyas and Şawmi'as}

In the Ottoman dynasty, takiya was a word used for naming khāngāhs in Egypt, Iran, India and Anatolia (Brown, 1357: Vol. 3, p. 90; Clayer, 2002: p. 415). From the frontage of Bāyazīd-I Basțāmī'skhāngāhs, it can be said that Şawmi'a is a 
word used for naming Sufis' buildings.

\section{Geographical Distribution of Sufis' Centers}

Iran: Organized khāngāhs were formed in the $5^{\text {th }}$ century and in the $7^{\text {th }}$ and $8^{\text {th }}$ centuries A. H., khāngāhs and Zawiyas were the gathering units in various cities in Iran. Different khāngāhs were established in the Ilkhanid and Timurid dynasties. Many khāngāhs were closed in the Sfavid dynasty and many Sufis immigrated to other countries. However, their activities re-started in the Qajarid period (Persian Encyclopedia, vol. 1, p. 645).

Iraq: Baghdad was one of the main centers of Sufism teachings and various Islamic sects and scientific debates. The first rebāț was built for Zahid al-Başrī in the $4^{\text {th }}$ century and the number of these centers reached 35 ones in Baghdad at the end of the $7^{\text {th }}$ century.

Syria: The first khāngāh in Syria that dedicated to Sufis was belonged to Abūlqāsim Samīsațī al-Demashqī (Sam’anī, 1962: d. 543 A. H.). in Halab city. 21 rebāțs were established in this city. Na'îmī al-Dimashqī (vol. 2, pp. 139-191) described 29 khāngāhs in Syria from the $5^{\text {th }}$ to $8^{\text {th }}$ centuries. Zawiya was used for naming khāngāhs before Uttoman dynasty (Farīd, 1981: p. 208). In the Ayyubid dynasty, Halab had about 20 khāngāhs (Farīd, 1981: p. 210).

Turkey: After the $7^{\text {th }}$ century A. H., Iranian migrated Sufis collaborated Turk bābās to publicize the Sufism in Anatolia. Movlavians helped the formation of such centers in this region (Aflākī, 1362 A. H.: Vol. 2, p. 694). The important khāngāh was one that was built around Movlavì's grave (Diki, p. 24).

Egypt: Şalāh al-DīnAyyūbī established the first formal khāngāh for placing Sufis. Cairo had 7 khāngāhs in the $8^{\text {th }}$ and $9^{\text {th }}$ centuries A. H. They developed in Mamluk period in the form of madrasas (Diki, p. 41).

Africa: In northern Africa (such as Libya, Tunis and Morocco), some Sufis' centers were established under the names of Zawiya and rebāț.

Central Asia: Balkh, Bukhārā and Samarkand were of main cities where khāngāhs were placed (Khandmir, vol. 4, p. 21), such as Bakhazris' khāngāh in Bukhārā as the main one (Jāmī, 1337: p. 419) and that of Shaykh Baha' al-DīnNaqshband (d. 791 A. H.) (Hashimi Gholpayghani, 1379: p. 187). The khāngāhs in this region were close to madrasas showing the relations between Sufis and madrasa groups (Golombek \& Wilber, 1988: p. 48).

Afghanistan: Hirat (Māyil Hirawī, 2001) was of the main khāngāh centers with the presence of Khawaja Abdallah Anșāin. Tymurids were active in building khāngāhs (Golombek \& Wilber, 1988: Vol. 1, p. 310).

Kashmir. The khāngāhs in this region were built in the period of MirrSayyid 'Alïfamazanī (d. 875 A. H.) of Kabrūyas under the name of Imam Ali $\mathrm{ipbuh}_{\text {). }}$ These centers were for teaching, worshiping and living in (Dihlawī 'Abd-al-Haqq, p. 168).

\section{The Educational Role of Sufis Centers}

The performance of khāngāhs and other related centers has been change based 
on different historical contexts. In addition to presenting religious programs and guidance, these centers converted to main centers for theoretical debates on educating followers in the $4^{\text {th }}$ century A. H. (Karamustafa, 2007: p. 116). These living homes of Sufis became gradually a place for ethical education in many Islamic countries. Sufis' adaptation with other sects tended them to affect other people from different races and social groups. This adaptation resulted in their great role in teaching Islamic sciences and due to competing the scientists of madrasas, their educational procedures had some hierarchy and order. Fiqh and Hadith trends make them teach Sufis Islamic knowledge, such as Koran interpretation, hadith narration, astronomy, literature and philosophy. Sufis tried to explain the religious aspects of Sufism in their teachings (Debāshī, 2005: p. 183).

The calm and silent corners of khāngāhs and zawiyas were appropriate for thinking, reading, writing and scribing. For example, after leaving Nazzamiyya

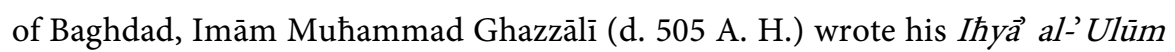
in khāngāhs (Kiyani, 1369: p. 378; Zarrīnkūb, 1364: p. 100). Some khāngāhs were dedicated to women where they taught reading, writing and Islamic knowledge.

With increasing the educational performance of khāngāhs, a group of scientists tended to read the books by Sufis and started to write Sufism books. For example, a group of scientists were reading and interpreting the books by Imām Muhammad Ghazzālī. Some scientists were reading and writing in the library of the khāngāh built by Shaykh Aћmad Jām in Jām city. The khangāh built by an Iranian Sufi, "Alla" al-Dawla Simnani had a library where many famous Sufis were reading and writing for about 100 years after his death (Homayoonfarokh, 1374: pp. 36-94).

In the introduction or the end of some manuscripts written by Sufis, there is a passage indicating it was written in a certain khāngāh (Image 4). This can be seen in the case of transcribing some manuscripts. It can be concluded that khāngāhs and similar centers functioned as main centers for writing books and transcribing manuscripts.

\section{Educational Performance of Sufis' Centers}

In their first periods of their establishment, khānqāhs and other Sufis' centers were places for staying and feeding Sufis as well as teaching social principle and human rights (Kiyani, 1369: p. 63) and the tradition of feeding guests, Sufis and travellers was so wide that Ibn Bațțūta (1987, p. 281) focused on it in his travel account. People conceived of some of these places as holy places. Some of them were centers of manifesting Iranian-Islamic music, art and poetry. Combining Sufism with training Islamic sciences, some of these centers had a main role in Islamic knowledge and its education, development and dissemination. The following examples are some historical evidences of this role:

1) Next to or inside of some khānqāhs, there was a madrasa for teaching Islamic sciences. Madrasa of khānqāh established by Husayn ibn Ya'qūb al-Nishabūrī in $4^{\text {th }}$ century A. H. was an example (Hākim Nīshabūrī, 1375). 
2) Some Sufism scientists were teaching their books in Khānqāhs, such as Ibn HayyānBustī in $4^{\text {th }}$ century A. H. who was teaching his authored books in hadith in Nishabūr (Sam'anī, 1962, vol. 2, p. 245).

3) Great educational-cultural institutions such as Rab' Rashīdī in $8^{\text {th }}$ century A. H. had some educational centers including among others Khānqāhs for teaching Sufism students and holding Sufism tradition and feeding the poor. An elder was teaching the Sufism students and guiding followers in these centers.

4) Teaching Sufism students was one of the main demands of some Sufism centers. In Shaykhū center in Egypt established by AmīrSayf al-DīnShaykhū in 1355 A.C, some lessons on hadith, fiqh, and Koran was taught by a dedicated elder for each subject (Maqrīzī, 1418 A. H.: Vol. 4, p. 292). One example was Bibersiya Khāngāh established by Rukn al-DīnBibersiya in 1306 A.C. (Maqrīzī, 1418 A. H.: Vol. 4, p. 292). This is the greatest Khāngāh in Egypt where hadith was taught and qurrā' (Koran readers) were daily reading Koran (Maqrīzī, 1418 A. H.: Vol. 4, p. 285).

5) Most Islamic scientists related to Khāngāhs, including among others Ibn Hajar A'sqalānī who instructed fiqh and hadith in Shaykhūnīya Khāngāh, and Jalal al-DīnŞayuțī (Sayūțī, 1387 A. H.) who instructed Sufism and hadith in the same khāngāh and Shahāb al-Dīn Mansūrī (d. 1482 A.C.), an Egyptian Sufism poet (Iz al-Dīn, 1410 A. H.: p. 47).

In all, Sufism centers focused on educating Sufism students and teaching theoretical and practical Sufism and conduct. However, they involved in educating Islamic sciences such as fiqh, hadith, Koranic interpretation, medicine and so on.

\section{Ups and Downs of Sufis' Centers in Historical Periods}

Khānqāhs and buq'as were of Sufis' main centers. Buq'as were developed from $5^{\text {th }}$ century A. H. during Saljuk Dynasty. The Sufism elders' buq'as (graves) were as their madrasas and khānqāhs where activities such as teaching, conducting and transcription were being done. In Safavid and Qajar periods, some bugh'as were built for Shia elders and Imams. For example, buq'a of Shaykh Şafĩ al-Dīn Ardabilī was highly considered in Safavid period and its library was developed. Shah Abbas dedicated the presented book collection of the palace to it (Homayoonfarrokh, 1342: p. 55; 1374: p. 102).

In parallel with the development of Sufism in Khurāsān and Fārs in $4^{\text {th }}$ century A. H., khānqāhs were developed (Persian Encyclopedia, under the entry, vol. 1, p. 880). Due to Mongols and Tatars' continuous attacks and before Safavid Dynasty, after-attack suffering resulted in people's tendency towards Sufism and developing Sufism centers throughout the country where teaching, conducting, writing and transcription were done (Zarrīnkūb, 1362 A. H.: p. 74). In Ilkhanid period, Sufism centers were developed throughout the empire and Sufis tried to do various activities there (Mortazavi, 1370: p. 312). Saljuks encouraged in developing Sufis' centers, too.

In the early years of $10^{\text {th }}$ century A. H., Shia was developed in Iran and Shia 
scientists were empowered. Sufis became weaker and Shia scientists and elders started to criticize Sufism tradition in their books and lectures (Persian Encyclopedia, under the entry "Sufism", vol. 1, p. 645). This caused Sufis to immigrate to other places and closing most khānqāhs. Since Sufis started to develop their activities in the early days of Qajar period, Shia scientists again criticized them seriously (Rajabi, 1381: p. 394). As Mīrzā Āghāsī had tendency to Sufism, Sufis were empowered again, but in short period of his governance as a vizier. However, Sufis continued to write, compile and transcribe (Persian Encyclopedia, under the entry "Sufism”, vol. 1, p. 645). HājMīrzā Muhammad HasanIsfahānī, known as Safi Alī Shāh (1251-1316 A. H.) was of Sufism elders in Qajar period that established a khānqāh in Tehran in the name of himself (Rajabi, 1381: p. 394).

\section{Results of the Study Manuscripts Transcribed in the Sufis' Centers}

In total, 68 manuscripts included at least one of the keywords. The writing place of 8 manuscripts and transcription place of 60 ones belonged to one certain Sufis' center. It is probable that many copies were transcribed in different centers. The lack of information on transcription place caused them not to be identified.

The details associated with these 60 manuscripts include:

\section{1) Diversity of Transcribing in Sufi's centers}

a) Khāngāhs

Studying 60 manuscripts, it can be said that there were various Sufi's centers. Of them, Khāngāhs (with 31) and Zawiyas and Mazārs (with 7 in each) were in the higher rank, respectively. Under general name as Khāngāh, they were dispersed in various countries and cities as shown in Table 1 . The frequencies of manuscripts in Keshmir (with 8), Iran (with 7) and Egypt (with 4) are in higher ranks, respectively.

\section{b) Other Centers}

In other centers of Sufis, not including Khāngās, transcription was common. Table 2 shows the transcription center name and frequencies of transcribed manuscripts in Sufi's centers other than Khāngāhs. Zawiyas (with 7 centers) and Mazārs (with 3 centers) had the higher ranks, respectively.

\section{2) Historical Periods}

The Sufi's transcription centers were active 7 - 13 centuries A. H. As Shown in Table 3, the 9 th century A. H. and the $8^{\text {th }}$ century A. H. had the higher ranks, with 20 and 11 manuscripts, respectively. The least rank belonged to $7^{\text {th }}$ century

A. H. with two transcribed items.

\section{3) Subject Dispersion}

Many subjects were included in the manuscripts transcribed in Sufi's centers. As Table 4 shows, the higher ranked subjects were Sufism (with 17 manuscripts) and Poet and philosophy and logic (with 10 manuscripts in each). 
Table 1. Various Sufi's centers.

\begin{tabular}{|c|c|c|c|c|}
\hline No. & Khāngāh's Name & $\begin{array}{l}\text { Number of } \\
\text { manuscripts }\end{array}$ & City & $\begin{array}{l}\text { Country (Number } \\
\text { of manuscripts) }\end{array}$ \\
\hline 1 & Amīrīye & 8 & Keshmir & Pakistan (8) \\
\hline 2 & Rub' Rashīiī & 2 & Tabrīz & \\
\hline 3 & Rashīd al-Dīn Fađll Allāh & 1 & Yazd & \\
\hline 4 & Hossayniye Ashrafiye & 1 & Yazd & \\
\hline 5 & Żahīr al-Dīn Mu'īn al-Īslām & 1 & Sawe & $\operatorname{Iran}(7)$ \\
\hline 6 & 'Imadiye Fiqhīye & 1 & Kerman & \\
\hline 7 & Sheykh Sāfĩ & 1 & Ardavil & \\
\hline 8 & Sheykhū & 1 & - & \\
\hline 9 & Melkiye Nașiriye & 1 & Cairo & \\
\hline 10 & Żuhriya & 1 & Cairo & Egypt (4) \\
\hline 11 & Rukniya & 1 & Cairo & \\
\hline 12 & Shahābiya & 1 & Hirat & \\
\hline 13 & Hirat & 1 & Hirat & Afghanistan (3) \\
\hline 14 & Īkhlașiya & 1 & Hirat & \\
\hline 15 & Seyyed Muћammad Mushtāq & 1 & Lekanhu & India (3) \\
\hline 16 & Samīsațiye & 1 & Demasque & Uzbekistan (1) \\
\hline 17 & Khawaje Muћammad Parsā & 1 & Bukhārā & Syria (1) \\
\hline 18 & Mużaffarīye & 1 & Arbìl & $\operatorname{Iraq}(1)$ \\
\hline 19 & Sheiykh Abulmoghith & 1 & - & - \\
\hline 20 & Bulghanj Khatūn & 1 & - & - \\
\hline
\end{tabular}

Table 2. Transcription center name and frequencies of transcribed manuscripts in Sufi's centers.

\begin{tabular}{ccccc}
\hline No. $\begin{array}{c}\text { Center's } \\
\text { Common Name }\end{array}$ & Center's Name & $\begin{array}{c}\text { Number of } \\
\text { manuscripts }\end{array}$ & City & Country \\
\hline Qāsim Şūbāshì & 1 & Suria & Turkey \\
'Abd al-'Ażīm & 1 & Tehran & Iran \\
& Mużaffariyya & 1 & Tabriz & Iran \\
1 & Mawlawiya & 1 & Shām & Syria \\
& Basțamiya & 1 & Halab & Syria \\
& Basțamiya & 1 & - & Egypt \\
& Mawlawiya & 1 & - & Egypt \\
& Nāșir Bukhārī & 5 & Bukhārā & Uzbekistan \\
& Sheykhayn & 1 & Sabzwar & Iran \\
& Mawlana & 1 & Qawniya & Turkey \\
\hline
\end{tabular}




\section{Continued}

\begin{tabular}{cccccc}
\hline & Shaykh Murtażā Anșāī & 4 & Hirat & Afghanistan \\
3 & Mrqad & Shaykh Burhān & 1 & Baghdad & Iraq \\
4 & Maqbara & Hāj Muhammad Ja'far & 2 & Tabriz & Iran \\
5 & Buq'a & Sayyid Ĥamza & 1 & Tabriz & Iran \\
6 & Dār al-Ta'līm & Sulțāniya & 1 & Qusțanțaniya & Turkey \\
7 & Madrasa & İkhlașiya & 1 & Hirat & Afghanistan \\
8 & Rub' & Rub' Rashīdī & 1 & Tabriz & Iran \\
9 & Masjid Jāmi' & Abāșufiya & 1 & Qusțanțaniya & Turkey \\
10 & Iqta' & Ālijah QuliKhān & 1 & Kābul & Afghanistan \\
11 & Şawmi'a & Amīrs Syyid Alī & 1 & Abiward & Iran \\
12 & Kinisa & Zirakiya & 1 & - & Egypt \\
\hline
\end{tabular}

Table 3. The Sufi's transcription centers were active 7 - 13 centuries A. H.

\begin{tabular}{cccccc}
\hline No. & Date & Century & Number in Khānghāhs & Number in other centers & Total \\
\hline 1 & $610-698$ & 7 & 2 & - & 2 \\
2 & $733-788$ & 8 & 9 & 2 & 11 \\
3 & $831-896$ & 9 & 12 & 8 & 20 \\
4 & $903-971$ & 10 & 2 & 5 & 7 \\
5 & $1011-1074$ & 11 & 5 & 8 & 10 \\
6 & $1191-1198$ & 12 & - & 1 & 6 \\
7 & $1277-1291$ & 13 & 32 & 38 & 4 \\
8 & total & $7-13$ & & & 60 \\
\hline
\end{tabular}

Table 4. Subjects were included in the manuscripts transcribed in Sufi's centers.

\begin{tabular}{ccccc}
\hline No. & Subject & Number in Khānghāhs & Number in other centers & Total \\
\hline 1 & Sufism & 15 & 2 & 17 \\
2 & Poet & 2 & 8 & 10 \\
3 & Philosophy and Logic & 7 & 3 & 10 \\
4 & Quran science & 3 & 3 & 6 \\
5 & Arabic Literature & 3 & 3 & 6 \\
6 & Kalam (Narration) & 1 & 2 & 3 \\
7 & Fiqh (Jurisprudence) & 1 & 3 & 4 \\
8 & Ethics & 1 & - & 1 \\
9 & Medicine & 1 & 1 & 1 \\
10 & Biography & 1 & 1 & 1 \\
11 & Extracts & - & 1 & \\
\hline
\end{tabular}




\section{The Difference among Transcription of Scientific Works in the Three Scientists' Centers}

Scientists considered transcription of their own works and those of others in all periods. Mosques, madrasas and sometimes, khānqāhs were of main centers for transcription of works by Muslim scientists. Since disseminating religious knowledge was common in mosques, teaching in madrasas and guiding and conducting in khānqāhs, these centers were all at work in transcription. However, scribes in Sufism centers tended to transcribe manuscripts on Sufism and its related sciences. Scribe in mosques and madrasas generally tried to transcribe manuscripts on Arabic grammar, figh, hadith and Koranic interpretation. It can be said that in these three centers (masques, madrasas and khānqāhs), transcription activity was focused on subjects educationally needed for each of the centers.

\section{Conclusion}

Sufi's centers, regardless of their special names, were not only for prayer and meditation during the $7^{\text {th }}-13^{\text {th }}$ centuries A. H., but also functioned as centers for training and doing transcription. Although Sufis tended to transcribe in various subjects, they mainly focused on Sufism. They were active in transcription during 8 and $9^{\text {th }}$ centuries A. $\mathrm{H}$.

The scientific perspective dominated in these centers was due to the activity of famous scientists in them. In addition, the existence of governors and kings agreed with Sufism movement were at work in encouraging the trend.

\section{Concluding Remarks}

Sufism centers were not only for worship and conduct from the $4^{\text {th }}$ and $5^{\text {th }}$ to $13^{\text {th }}$ centuries A. H. They had some educational and scientific activities, including among others, transcription. This trend has been developed in the $8^{\text {th }}$ and $9^{\text {th }}$ centuries A. H. due to Mongols and Tatars' continuous attacks and before Safavid Dynasty. Shia' scientists wrote some books against Sufis and Sufism and their deviations in Safavid period. This resulted in decrease in Sufis' power. In addition, Sufism encountered some deviations and Sufis were distanced from some of their main principles and various sects were created in Sufism. This in turn caused displacement of Sufism centers as scientific centers.

Scientific centers belonged to Sufis were mostly khānqāhs and then, zawiyas, madrasas and buq'as. Khānqāhs were historically the most formal place for Sufis and teaching Sufism and making its tradition. In addition, most khānqāhs were established in Ilkhanid Dynasty. Considering the development of Sufism in Khurāsān and Fārs during and after the $4^{\text {th }}$ and $5^{\text {th }}$ centuries A. H., it can be said that studied khānqāhs were mostly located in Iran. After Iran, Egypt had more khānqāhs due to the approach taken by Mamluk Dynasty (648 - 923 a.h.) in building and reconstructing educational and scientific centers, such as masques, madrasas, khānqāhs and their consequent serious educational role and writing 
activity throughout the country.

Scribes in Sufis' centers tended to transcribe manuscripts on Sufism. This was rational as their educational aim was to develop Sufism school and thought.

\section{Conflicts of Interest}

The author declares no conflicts of interest regarding the publication of this paper.

\section{References}

Aflākī, A. ibn A. N. (1362 A. H.). Manāqib al-'Arifinn (Virtues of Mysticism). By Taћsīn Yāzijī. Ankara: 1959-1961, Offset on Tehran.

Ālūsī, 'Ā. (1398). Al-Rabț al-Baghdādiyafí al-TārīkhwaKhaț̦t (Rabat in Baghdads History). Al-Mawred, Vol. 8. No. 1.

Brown, E. G. (1357). Iran Literature History. Translated and Annotated by Ali AsgharHikmat, Tehran.

Clayer, N. (2002). Tekke. Encyclopedia of Islam. P.y. Bearman. Th. Bianquis, C.E. Bosworth, Vol.10, Liden, Brill.

Dastgheib, A. (1376 A. H.). Mongol Invasion in Iran. 'Ilm Pub.

Debāshī, H. (2005). The Historical State of Iranian Sufism in Saljuk Period. Leonard Luizon, trans. MajdaldinKeywani. Tehran: Markaz.

Derayatimostafa (2012-2016). Union Catalogue of Iran Manuscripts (Volum 1-40). Tehran: National library of Iran.

Dickie, J. (1984). Allah and Eternity: Mosques, Madrasa and Tombs in Architecture of Islamic World. Ed. George, Michell, London: Thames and Hudson.

Fadā'ī̄̄āqī, G. (2007). Introduction to Arabic and Persian Manuscripts and Rare Books. Tehrān: SAMT Pub.

Farīd, H. (1981). al-Rebțwa al-Khawanīqwa al-Zawayawa al-Takāyafī Madīna al-Halab (Rabat and monasteries, and ...in Aleppo). al-Hawliyyat al-Athariyya al-Sūriya, 31, No. 1,2 .

Golombek, L., \& Wilber, D. N. (1988). The Timurid Architecture of Iran and Turan, Princeton.

Hākim Nīshābūrī, M. (1375). The History of Nīshābūr (City). Translated by Khalifa Nishaburi. Tehran: Aghah.

Hashimi Golpaygani, M. M. (1379 A. H.). Islamic Historical Traces in Transoxiana. Trans. Bahram Shadabi. Tehran.

Homayoonfarrokh, R. al-D. (1342 A. H.). The History of Iran's Libraries. Tehran: Tehran Municipality.

Homayoonfarokh, R. al-D. (1374 A. H.). Iran's Royal Books and Libraries: The History of Iran's Libraries. Tehran: Culture and Art Ministry.

İbn Bațțūța. R. (1987). The Journey. By Muhammad Abd al-Mun’im ‘Uryān. Beirut.

Ibn, J. (1984). Riћla (The Journey). Beirut.

Iz al-Dīn, M. K. (1410 A. H.). Scientific Movement in Mamluk Dynasty in Egypt. Bayrūt: 'Ilm al-kitāb.

Jāmī, A.-R. ibn A. (1337). Nafahat al-'Uns (Blowing of Friendship). By Mahdi Tawhidi, Tehran. 
Karamustafa, A. (2007). Sufism: The Formative Period. Cambridge: Edinburgh University Press.

Khawandmir, M. A. (1305). Niżām Dictionary. Haydarabad Dakan.

Kiyani, M. (1369 A. H.). Khagāhs History in Iran. Tehran: Tahoori.

Maqdisī, M. ibn A. (1906). Aћsan al-TaqāsìmfìMa'rifa al-Aqālīm (The Best Division in the Knowledge of the Regions). Leiden.

Maqrīzī, A. (1418 A. H.). Khițaț: Mawaizwa al-'T'tibar bi Dhikr al-Khitatwa al-'Athar (Plans of Preaching and Consideration in Mentioning Territories and Effects) (2 Vols.). Cairo: Bulaq.

Māyil Hirawī, N. (2001). History of Book-Making and Critical Correction of Manuscripts. Tehrān: Iran Parliament Central Library. (In Persian)

Mortazavi, M. (1370 A. H.). Issues on Ilkhanid Period. Aghah Pub.

Mușțafā, J. (2006). aL-Rebț al-Şawfiya al-BaghdādiyawaAtharuhā fi Thaqafa al-Islāmiya (Rabat of Sufi in Baghdad and Its Effects in Islamic Culture). Bairut.

Rajabi, M. H. (1381). Iran's Libraries. In Encyclopedia of Library and Information Science (Vol. 1). Tehran: National Library of Iran.

Sam'anī, A. (1962). Al-Ansāb (The Ancestors and Affiliates). Haydarabad Dakan: 'Othmāniyya Encyclopedia.

Sayūțī, 'A. al-R. (1387 A. H.). Husn al-Muћāzira (Good Lecturer in the History of Egypt

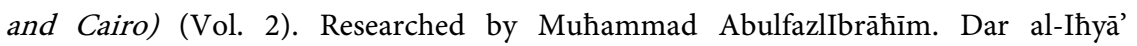
al-Kutub al-A'rabī.

Trimingham, J. S. (1971). The Sufi Order in Islam. Oxford: Oxford University Press.

Walī, M. Ț. (1988). Al-Masājidfì al-Islīm (Mosques in Islam). Bairut.

Zarrīnkūb, A.-al-H. (1362 A. H.). The Value of Sufism Heritage. Tehran: Amir Kabir Pub. Co.

Zarrīnkūb, A.-al-H. (1364 A. H.). Escaping from the School. Tehran: Amir Kabir. 